\section{Morphological and Genetic Variation among Four High Desert Sphaeralcea Species}

\author{
Chalita Sriladda ${ }^{1}$ \\ Department of Plants, Soils, and Climate, Utah State University, 4820 Old \\ Main Hill, Logan, UT 84322
}

\author{
Heidi A. Kratsch \\ University of Nevada Cooperative Extension, University of Nevada, 4955 \\ Energy Way, Reno, NV 89502
}

Steven R. Larson

Forage and Range Research Laboratory, USDA-ARS, Utah State University, Logan, UT 84322

\section{Roger K. Kjelgren \\ Department of Plants, Soils, and Climate, Utah State University, 4820 Old Main Hill, Logan, UT 84322}

Additional index words. Sphaeralcea coccinea, Sphaeralcea grossulariifolia, Sphaeralcea munroana, Sphaeralcea parvifolia, globemallow, AFLP

\begin{abstract}
The herbaceous perennial species in the genus Sphaeralcea have desirable drought tolerance and aesthetics with potential for low-water use landscapes in the Intermountain West. However, taxonomy of these species is ambiguous, which leads to decreased consumer confidence in the native plant nursery industry. The goal of this study was to test and clarify morphological and genetic differentiation among four putative Sphaeralcea species. Morphological characteristics of the type specimens were used as species references in canonical variate analysis to generate a classification model. This model was then used to assign putative species names to herbarium voucher specimens and to field-collected voucher specimens to clarify genetic variation among species. Field specimens were also classified using Bayesian cluster analyses of amplified fragment length polymorphism (AFLP) genotypes. Sphaeralcea coccinea (Nutt.) Rydb. and $S$. grossulariifolia (Hook. \& Arn.) Rydb. formed a composite group morphologically and genetically distinct from the $S$. munroana (Douglas) Spach and $S$. parvifolia A. Nelson composite group. Each composite group displayed genetic isolation by geographic distance. Also, morphological traits of $S$. munroana and $S$. parvifolia correlated to geographic distance. Taken together these results suggest that our samples represent two sympatric yet reproductively isolated groups. Distinguishing between these two Sphaeralcea composite groups can create greater consumer confidence in plant material developed for use in Intermountain West low-water landscaping.
\end{abstract}

Globally, urbanization has dramatically increased with nearly half of the world's population currently living in urban areas; it is expected that approximately three-fourths of the world's population will be living in urban areas by the year 2025 (United Nations, 2012). Substantial increases in urban population lead to increased demand for water in commercial, industrial, and residential sectors (Foster and Beattie, 1979). This increased demand in arid and semiarid urban regions means

Received for publication 16 Feb. 2012. Accepted for publication 10 Apr. 2012.

We thank Linnea Johnson for help in genetic laboratory works. We thank Mary Barkworth and Michael Piep for facilitating the loan of type specimens.

${ }^{1}$ To whom reprint requests should be addressed; e-mailsriladda@gmail.com. facing the additional challenge of absolute water scarcity (Vorosmarty et al., 2000).

Demand for urban green spaces, including urban landscapes, is increasing with population growth because those spaces provide aesthetic and mental health benefits and a positive association with the perceived general health of residents (Maas et al., 2006). Urban green spaces also mitigate a number of undesirable environmental effects such as urban heat islands (Deloya, 1993). Many urban green spaces require irrigation, particularly in arid and semiarid areas. Thus, increasing irrigation for urban landscapes is causing an increased demand for more efficient watering systems. Low-water landscaping describes landscapes full of plants that use substantially less water. Therefore, low-water landscaping is a key tool for conserving water in irrigated urban landscapes, particularly in arid and semiarid areas (Kjelgren et al., 2009).
Drought-tolerant plants, including native species adapted to arid or semiarid regions, are key elements for successful low-water landscapes because they require little maintenance, provide a natural look to the landscape (Cane and Kervin, 2009; Kjelgren et al., 2009; McKinney, 2002), and honor natural habitats. Native plant landscaping also supports local economies, facilitating sustainability in urban systems at multiple levels. However, lack of native plant availability, cost of native plant materials, inconsistent and unreliable demand, and lack of production knowledge have minimalized the native plant market (Peppin et al., 2010).

The U.S. Intermountain West (IMW) is arid to semiarid and has an abundance of woody and herbaceous perennial native plants that are drought-tolerant and ornamentally attractive (Intermountain Native Plant Growers Association, 2012; Kratsch, 2011; Mee et al., 2003; Meyer et al., 2009). The genus Sphaeralcea (Malvaceae), commonly known as globemallow, is an annual-perennial herb or shrub wildflower characterized by brilliant, largely orange, flowers. Approximately 40 species of the genus are found throughout temperate North and South America (Holmgren et al., 2005). The genus Sphaeralcea includes 27 species in North America, from southern Canada through the western United States to northern Mexico, with disjunct populations in temperate South America (Holmgren et al., 2005). Several of these species appear to have both aesthetic and drought-tolerance qualities that lend them well to low-water landscaping (Intermountain Native Plant Growers Association, 2012; Mee et al., 2003); however, they are ostensibly closely related and difficult to distinguish. Four promising low-water landscape species, $S$. coccinea, S. grossulariifolia, S. munroana, and S. parvifolia, are commonly found in the IMW (Holmgren et al., 2005; Ring, 2005; Ring and Cully, 2007; Ring et al., 2009), and they are particularly difficult to distinguish from one another (Holmgren et al., 2005).

Polyploidy and hybridization have been reported as factors contributing to weak morphological differences among species in the genus (La Duke and Northington, 1978). Tate (2002) suggested the possible importance of geographical isolation for speciation. Analysis of nuclear ribosomal DNA internal transcribed spacer (ITS) sequences showed that the North American Sphaeralcea species [S. angustifolia (Cav.) G. Don and S. wrightii A. Gray] cluster together as do the two South American taxa ( $S$. crispa Hook. ex Baker f. and S. philippiana Krapov.) (Tate, 2002). Intergradation among species challenged early taxonomists in their efforts to clearly identify Sphaeralcea species using only morphological distinctions.

These four IMW species are being promoted by the nursery industry (Intermountain Native Plant Growers Association, 2012), but it is difficult to determine which species are actually being sold. Difficulty in determining species decreases consumer confidence in these species. Leaf morphology was used as 
the first taxonomic key to separate these species into two groups (Holmgren et al., 2005). Shallowly lobed leaves putatively separate $S$. munroana and $S$. parvifolia from $S$. grossulariifolia and $S$. coccinea, whose leaves are deeply lobed, cleft more than halfway to the base, and, in many, cleft to the base. However, $S$. munroana is often difficult to distinguish from $S$. parvifolia, whereas $S$. grossulariifolia can be easily confused with $S$. coccinea and some specimens of $S$. munroana (Holmgren et al., 2005). Besides leaf morphology, the mature fruiting carpel characteristics, density of leaf hairs, and hair ray orientation sometimes are used as keys for taxonomists to identify specimens (Atwood and Welsh, 2002). However, these characters are seldom used in practical settings and are not efficient for field use or for non-taxonomist collectors. The intergrading morphology of these species might be a result of genetic overlap and makes selection for superior forms difficult.

In terms of the geological distribution of the four species (United States Department of Agriculture, 2012), S. coccinea is found extensively throughout the IMW, and $S$. grossulariifolia is found throughout the Great Basin, generally toward the western part of the IMW. Distribution of S. munroana and $S$. parvifolia overlaps in Nevada, Utah, and Colorado, where S. parvifolia is distributed further south and $S$. munroana distributed further north. In Utah, where the distributions of the four species overlap, geographical differences seem to play an important role in putative species distribution, particularly for S. munroana and S. parvifolia, which occur in the north and south, respectively (Shultz et al., 2012). The distribution has sometimes been used as a key for species identification because of identification difficulty resulting from morphological overlap among these species.

Difficulty in their accurate identification creates concerns for those collecting Sphaeralcea seed for nursery production and reduces consumer confidence in the native plant industry, with plants varying widely in morphology being sold as the same species. The goal for this study was to clarify morphological and genetic distinctions among the four Sphaeralcea species, $S$. coccinea, $S$. grossulariifolia, $S$. munroana, and $S$. parvifolia, which may facilitate superior cultivar selections for use in low-water landscapes.

\section{Materials and Methods}

Type specimens of the four Sphaeralcea species were used as references. We borrowed all available type specimens (holotype/isotype) representing the four species from herbaria across the United States and Great Britain. In Summer 2008, we collected field specimens from 20 populations in Utah (Fig. 1). Natural population collection sites for field sampling were preliminarily located from geographic coordinates taken from Utah State University (USU) Intermountain Herbarium voucher specimens of the four species. However, the putative Sphaeralcea

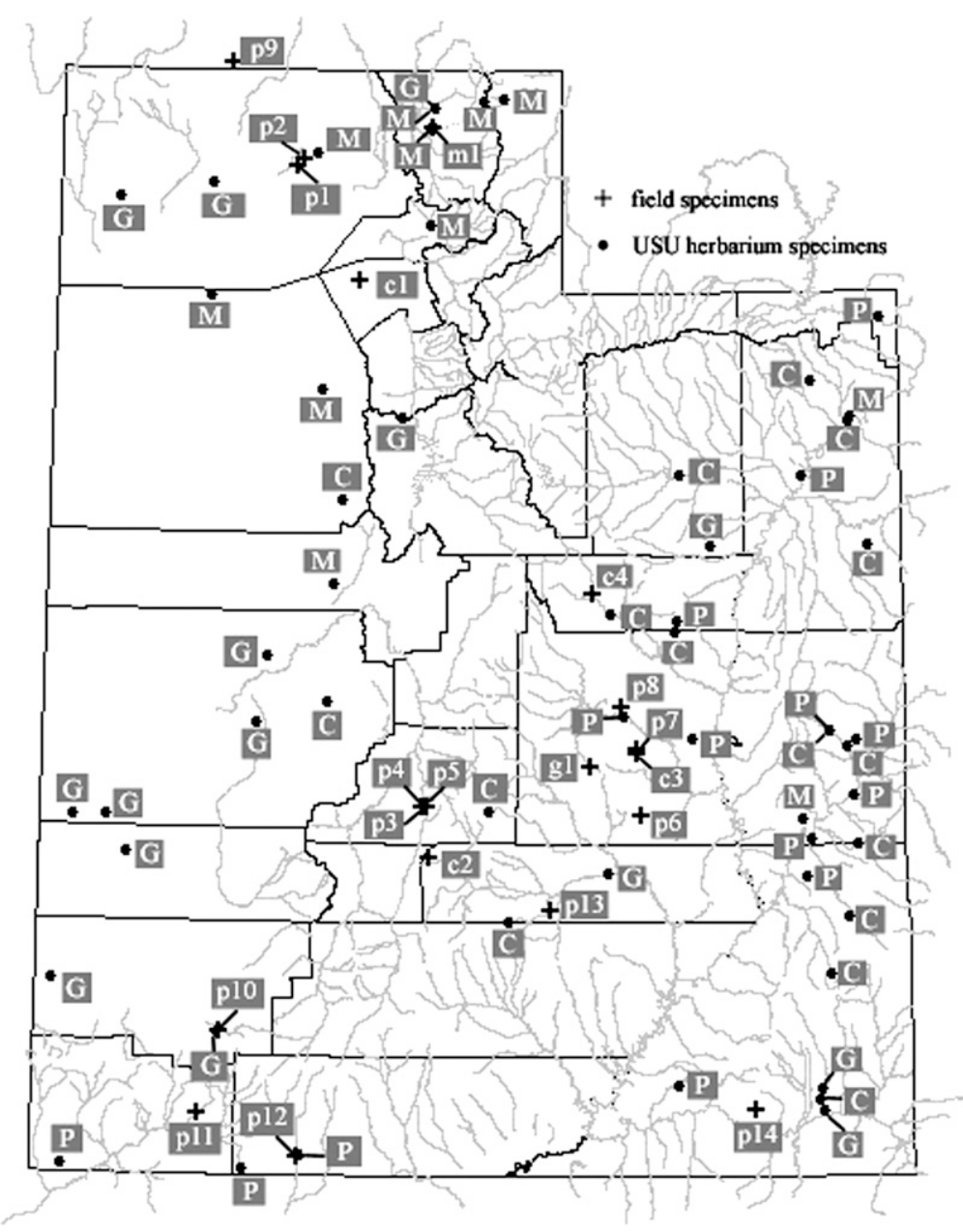

Fig. 1. Geographical distribution of Sphaeralcea species in Utah used in this study; letters were used to indicate species names; capital letters represent herbarium specimens $(\mathrm{C}=S$. coccinea; $\mathrm{G}=S$. grossulariifolia; $\mathrm{M}=S$. munroana; $\mathrm{P}=S$. parvifolia); lower-case letters represent field-collected specimens (c $=S$. coccinea $; \mathrm{g}=S$. grossulariifolia $; \mathrm{m}=S$. munroana; $\mathrm{p}=S$. parvifolia).

populations were no longer present at many of the field sites. We were able to find other Sphaeralcea populations, although not always of the same species, during these collection trips. At each site, three voucher specimens collections, GPS coordinates, and soil samples were collected. The field specimens were then used for genetic and correlation analysis. In addition to the collected field specimens, existing Intermountain Herbarium voucher specimens were also used to investigate morphological variation within and among species.

Morphology and canonical classifications. Morphological variation within and among type specimens were evaluated by measuring 10 morphological characteristics of fully mature leaves (three leaves per plant) (Table 1). Analysis of variance (ANOVA) for these morphological measurements was performed using PROC GLM in SAS software (SAS Institute, Cary, NC) to test for possible differences among species. Canonical variate analysis (CVA), performed with NTSYSpc $2.2 \mathrm{~N}$ software (Exeter Software, Setauket, NY), was used to generate a model for the purpose of assigning field and existing herbarium specimens to one of four putative Sphaeralcea species groups.

We selected 15 to 16 existing USU herbarium specimens of each species from different locations in Utah (Fig. 1) for morphological study. Similar to the type specimens, 10 morphological characteristics were measured on fully mature leaves (three leaves per plant). Morphological characteristics of the herbarium specimens were subjected to CVA to assign putative species names based on the classification model. Morphological variation among species was determined based on deviation of species assignment to their type groups.

Morphological characters were measured from the three voucher specimens taken at each field population. Similar to the type specimens, three fully mature leaves from each plant were used to measure 10 morphological characteristics. Morphological characteristics of the field specimens were subjected to CVA to assign putative species names on the basis of the classification model of the type specimens. The assigned species names of the field specimens were later used for the genetic variation and correlation analysis. 
Table 1. Means (range) for morphological characteristics for type specimens among putative Sphaeralcea species, including $S$. coccinea (n = 8), S. grossulariifolia $(\mathrm{n}=5)$, . munroana $(\mathrm{n}=3)$, and $S$. parvifolia $(\mathrm{n}=17)$.

\begin{tabular}{|c|c|c|c|c|}
\hline Character & S. coccinea & S. grossulariifolia & S. munroana & S. parvifolia \\
\hline$\overline{\text { Petiole length }(\mathrm{mm})^{\mathrm{z}}}$ & $10.63(5.7-20.0)^{\mathrm{a}}$ & $14.67(7.0-17.7)^{\mathrm{a}}$ & $8.72(5.8-10.3)^{\mathrm{a}}$ & $14.02(8.5-25.3)^{\mathrm{a}}$ \\
\hline Midlobe length (mm) & $19.88(8.0-35.7)^{\mathrm{a}}$ & $25.53(24.7-26.3)^{\mathrm{a}}$ & $22.44(19.7-26.7)^{\mathrm{a}}$ & $20.55(12.0-27.3)^{\mathrm{a}}$ \\
\hline Midlobe width (mm) & $3.31(1.0-6.3)^{\mathrm{b}}$ & $4.67(4.3-5.7)^{\mathrm{b}}$ & $3.72(3.3-4.3)^{\mathrm{b}}$ & $10.60(7.0-15.7)^{\mathrm{a}}$ \\
\hline Secondary lobe length (mm) & $13.08(5.7-19.3)^{\mathrm{a}}$ & $17.47(16.0-21.0)^{\mathrm{a}}$ & $14.33(12.2-15.7)^{\mathrm{a}}$ & $14.14(8.0-18.3)^{\mathrm{a}}$ \\
\hline Secondary lobe width (mm) & $2.56(1.0-4.0)^{\mathrm{b}}$ & $3.57(3.0-4.0)^{\mathrm{b}}$ & $2.78(2.7-2.8)^{\mathrm{b}}$ & $8.30(4.3-12.3)^{\mathrm{a}}$ \\
\hline Lobe depth $(\%)$ & $97.00(80.0-100.0)^{\mathrm{a}}$ & $83.00(60.0-100.0)^{\mathrm{a}}$ & $51.00(30.0-70.0)^{\mathrm{b}}$ & $22.00(3.0-50.0)^{\mathrm{c}}$ \\
\hline Maximum number of flowers/node & $1.00(1.0-1.0)^{\mathrm{b}}$ & $5.20(4.0-6.0)^{\mathrm{a}}$ & $4.33(4.0-5.0)^{\mathrm{a}}$ & $5.59(1.0-9.0)^{\mathrm{a}}$ \\
\hline Pedicel length (mm) & $3.08(2.0-4.0)^{\mathrm{a}}$ & $2.90(1.7-3.7)^{\mathrm{a}}$ & $2.89(2.0-3.7)^{\mathrm{a}}$ & $2.99(1.7-5.0)^{\mathrm{a}}$ \\
\hline Calyx length (mm) & $6.67(4.0-9.0)^{\mathrm{a}}$ & $5.73(4.7-6.7)^{\mathrm{a}}$ & $5.89(5.7-6.0)^{\mathrm{a}}$ & $6.54(5.2-8.0)^{\mathrm{a}}$ \\
\hline Petal length (mm) & $12.33(7.0-19.0)^{\mathrm{a}}$ & $11.73(9.3-14.7)^{\mathrm{a}}$ & $11.00(10.0-11.7)^{\mathrm{a}}$ & $11.65(5.0-14.3)^{\mathrm{a}}$ \\
\hline
\end{tabular}

${ }^{\mathrm{z}}$ Values within a row with different letters indicate statistical significance at $\alpha=0.05$. The type specimens (holotype and isotype) were on loan from Harvard

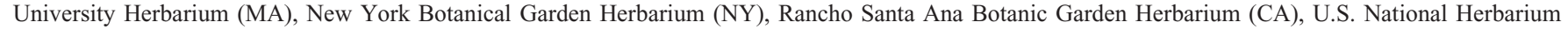
(Washington, DC), and Royal Botanical Garden, Kew Herbarium (UK).

Genetic analysis. Leaf samples (two to three leaves per plant) collected from each field population (12 plants per population) were dried in 28 to 200 mesh silica gel (Fisher Scientific, Pittsburgh, PA). DNA was extracted with the DNeasy 96 Plant Kit (Qiagen, Valencia, CA). AFLPs were assayed as described by Vos et al. (1995) with described modifications. The DNA samples were preamplified with EcoRI +1/MseI +1 using A/C selective nucleotides. Selective amplification primers consisted of five EcoRI $+3 / \mathrm{MseI}+3$ primer combinations using $\mathrm{AAG} / \mathrm{CAG}, \mathrm{ACT} /$ CAG, ACT/CTC, ACT/CAC, and ACA/CTG selective nucleotides. The EcoRI selective amplification primers included a fluorescent 6-FAM (6-carboxy fluorescein) label on 5' nucleotides. Selective amplification products were combined with GS600 LIZ internal lane size standard and were fractionated using an ABI 3730 instrument with $50-\mathrm{cm}$ capillaries and sized between 50 and 600 bp with Genescan software (Applied Biosystems, Foster City, CA). Although DNA molecules vary in length by increments of $1 \mathrm{bp}$, the relative mobility of bands is also affected by sequence composition. Thus, non-homologous bands of the same length may not have the same relative mobility. Genescan trace files for each individual were visually analyzed for the presence or absence of DNA bands in bins that were at least 0.3 bp or more apart using Genographer software (available at $<$ http://hordeum.oscs. montana.edu/genographer/ $>$ or directly from the author, Tom Blake, at blake@hordeum. oscs.montana.edu). Bayesian clustering of individual plants without a priori assignment of individuals to hierarchical groups was used to determine genetic structure and to test for possible admixture between taxa, which might otherwise confound phylogenetic analysis, using Structure Version 2.1 (Pritchard et al., 2000). Three analyses were used on each model with 100,000 iterations and 10,000 burn-in or 200,000 iterations and 20,000 burn-in with the dominant-allele, admixture model of Structure Version 2.2 (Falush et al., 2007; Pritchard et al., 2000).

Correlation tests among morphology, genetics, and geographic origin. Morphological, genetic, and geographical distance matrices of the field specimens were used for correlation tests. Fifteen field populations were used for the correlation tests. The Euclidean distance matrix of morphology and NEI-72 distance matrix of genetics were computed using NTSYSpc 2.2N software (Exeter Software, Setauket, NY). Geographic distance matrix was computed in Geographic Distance Matrix Generator Version 1.2.3 (Center for Biodiversity and Conservation, the American Museum of Natural History, New York, NY). Mantel's correlation tests (Mantel and Valand, 1970) were performed with 999 permutations in the NTSYSpc $2.2 \mathrm{~N}$ software (Exeter Software). We also constructed neighbor-joining clustering trees to compare similarity in classification between distance matrices of morphology and genetics of the field-collected specimens using NTSYSpc $2.2 \mathrm{~N}$ software (Exeter Software).

\section{Results}

Morphology and canonical classifications. Morphological variation among the type specimens was mostly described by leaf lobing. Four of 10 morphological characters were significantly different among species in ANOVA, including lobe depth, midlobe width, secondary lobe width, and number of flowers per node (Table 1). Lobe depth separated type specimens into three distinct groups with $S$. coccinea and $S$. grossulariifolia having more than $80 \%$ lobe depth. Shallow leaf lobing associated with wide midlobe width and secondary lobe width separated $S$. parvifolia from the other species. Having only one flower at a node separated $S$. coccinea from the other species. According to CVA of the type specimens, the first component accounted for $92 \%$ of the morphological variation among species (Table 2). This suggests the classification model on the basis of the 10 morphological characters of the type specimens was powerful enough to use as a species reference. Again, lobe depth contributed most to the variation followed by midlobe width and secondary lobe width, respectively.

Morphological characteristics of S. grossulariifolia were similar to $S$. coccinea, as $75 \%$ of $S$. grossulariifolia USU herbarium specimens were assigned to the type group of S. coccinea (Table 3; Fig. 2). Meanwhile, only $6 \%$ of the $S$. coccinea USU herbarium specimens fell into the type group of $S$. grossulariifolia. Morphological characteristics of $S$. munroana were very similar to $S$. parvifolia, as all USU herbarium $S$. munroana specimens were assigned to the $S$. parvifolia type group based on the classification model, and all of the USU herbarium specimens of $S$. parvifolia fell into their type group.

Our morphological studies support the suggestion by Holmgren et al. (2005) that $S$. grossulariifolia can be easily confused with $S$. coccinea; and S. munroana can be confused with $S$. parvifolia. All USU herbarium $S$. munroana specimens fell into the type group of $S$. parvifolia, supporting the suggestion by Holmgren et al. (2005) that $S$. munroana and $S$. parvifolia may be no more than varietally different. Morphological characteristics distinguish these four putative taxa into two groups: $S$. coccinea and $S$. grossulariifolia and $S$. munroana and S. parvifolia. However, some USU $S$. grossulariifolia specimens collected in Cache County of northern Utah where S. munroana co-occurs (Shultz et al., 2012) fell into the type group of $S$. munroana. Overlap in morphological characteristics between these two putative species may be a result of interspecific hybridization. Holmgren et al. (2005) reported that some collections from the distributional range where $S$. munroana overlaps that of $S$. grossulariifolia appear to be first-generation hybrids between the two putative species.

Genetic analysis. The field population assigned as $S$. grossulariifolia on the basis of the classification model of the type specimens (Fig. 2) grouped together with populations assigned as $S$. coccinea, whereas the population assigned as $S$. munroana grouped together with populations assigned as $S$. parvifolia in the Bayesian cluster analysis (Fig. 3A-C). Separation of the $S$. coccinea and $S$. grossulariifolia composite group from the $S$. munroana and $S$. parvifolia composite group occurred when testing a two-population model $(K=2)$ in the structure analysis and remained separated when increasing the number of test populations in the model to three and four. Genetic variation was relatively greater within the composite group $S$. munroana and $S$. parvifolia, specifically within populations of $S$. parvifolia when the presumed number of populations in the model was increased. The population assigned as S. munroana also shared $\approx 20 \%$ genetic similarity with the composite group of $S$. grossularifolia and $S$. coccinea. 
Genetic distinctiveness between the two composite groups was consistent with morphology, again supporting suggestions by Holmgren et al. (2005) that S. munroana may be no more than varietally different from $S$. parvifolia. All USU S. munroana

herbarium specimens fell into the $S$. parvifolia type group, and the field population assigned as $S$. munroana grouped genetically with $S$. parvifolia. Similarly, our morphological and genetic studies suggest minimal varietal differences between $S$. grossulariifolia and

Table 2. Principal component in canonical variate analysis of morphological characters for type specimens of S. coccinea $(\mathrm{n}=8)$, S. grossulariifolia $(\mathrm{n}=5)$, S. munroana $(\mathrm{n}=3)$, and $S$. parvifolia $(\mathrm{n}=17)$.

\begin{tabular}{lccr}
\hline Morphological Traits & Component 1 & Component 2 & Component 3 \\
\hline Petiole length (mm) & 0.6093 & -0.1236 & 0.5630 \\
Midlobe length (mm) & -1.2335 & -0.3611 & -0.9685 \\
Midlobe width (mm) & 1.1507 & -1.6038 & 0.8345 \\
Secondary lobe length (mm) & 0.2947 & 1.4056 & 0.8925 \\
Secondary lobe width (mm) & 0.6142 & -0.3122 & 0.1624 \\
Lobe depth (mm) & -2.5134 & -1.2082 & 1.1876 \\
Number of flower per node & 0.3356 & 1.0642 & 0.0845 \\
Pedicel length (mm) & 0.4761 & -0.1044 & 0.0343 \\
Calyx length (mm) & 0.4654 & -0.1782 & -0.3516 \\
Petal length (mm) & -0.5647 & -0.1586 & -0.0607 \\
Variation (\%) & 92.3100 & 6.1600 & 1.5300 \\
\hline
\end{tabular}

Table 3. Percentage of numbers of existing Utah State University Herbarium specimens of the four putative Sphaeralcea species assigned to its type group based on the classification model generated from morphological characteristics of the type specimens in the canonical variate analysis.

\begin{tabular}{|c|c|c|c|c|}
\hline \multirow[b]{2}{*}{ Herbarium specimens ${ }^{y}$} & \multicolumn{4}{|c|}{ Type specimens ${ }^{z}$} \\
\hline & $\begin{array}{l}\text { S. coccinea } \\
(\mathrm{n}=8)\end{array}$ & $\begin{array}{l}\text { S. grossulariifolia } \\
(\mathrm{n}=5)\end{array}$ & $\begin{array}{l}\text { S. munroana } \\
(\mathrm{n}=3)\end{array}$ & $\begin{array}{l}\text { S. parvifolia } \\
(\mathrm{n}=17)\end{array}$ \\
\hline S. coccinea $(\mathrm{n}=16)$ & $93.75 \%(15)$ & $6.25 \%(1)$ & - & - \\
\hline S. grossulariifolia $(\mathrm{n}=16)$ & $75.00 \%(12)$ & $12.50 \%(2)$ & $12.50 \%(2)$ & - \\
\hline S. munroana $(\mathrm{n}=15)$ & - & - & - & $100.00 \%(15)$ \\
\hline S. parvifolia $(\mathrm{n}=16)$ & - & - & - & $100.00 \%(16)$ \\
\hline
\end{tabular}

S. coccinea, as $75 \%$ of the USU herbarium specimens of $S$. grossulariifolia fell into the type group of $S$. coccinea, and the field population assigned as $S$. grossulariifolia grouped genetically with $S$. coccinea in the structure analysis. Morphological and genetic distinctions appeared to be greatest between $S$. coccinea and $S$. parvifolia. It is possible that putative species $S$. coccinea and $S$. parvifolia have evolved in different ecological niches, leading to genetic distinctions. This is similar to the findings of Tate (2002) who classified other Sphaeralcea species into North America and South America groups based on ITS genetic data.

Bayesian cluster analysis showed that the field population assigned as $S$. munroana shared $\approx 20 \%$ ancestry with the composite group of S. grossulariifolia (Fig. 3A-C). Shared ancestry supports the possibility of some degree of interspecific hybridization between $S$. grossulariifolia and $S$. munroana as suggested by Holmgren et al. (2005) resulting in morphological overlapping between the two, because reciprocally some of the USU herbarium specimens of $S$. grossulariifolia fell into the type group of $S$. munroana.

Only one population of 20 populations from the field collection was assigned as $S$. grossulariifolia; and only one population was assigned as $S$. munroana based on the classification model (Fig. 2). Small sample sizes of the putative species $S$. grossulariifolia or $S$. munroana species may be the result of few extant populations, although we used locations identified from existing USU Herbarium

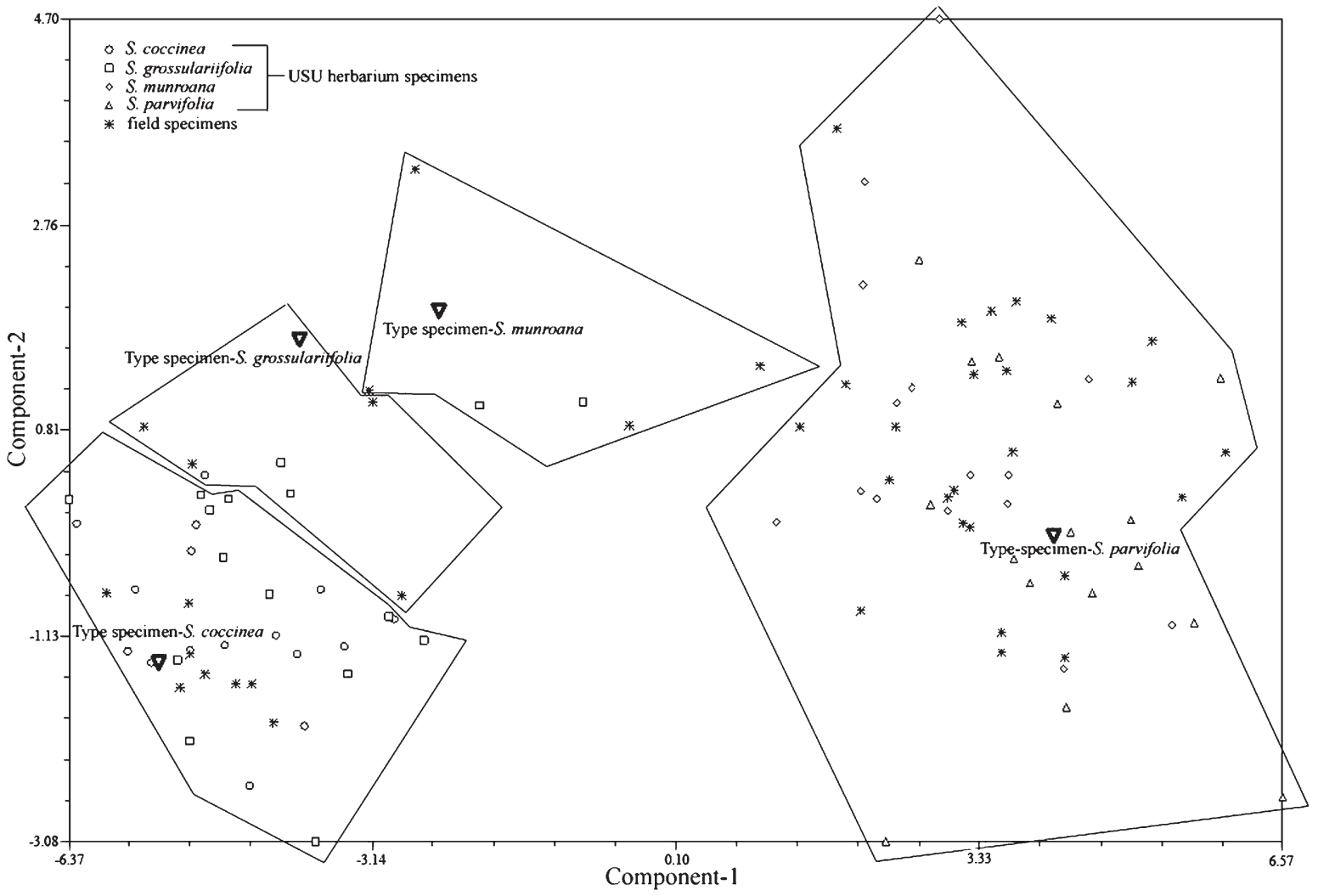

Fig. 2. Putative species name assignment of herbarium specimens and field-collected specimens on the basis of the classification model generated based on morphological characteristics of the type specimens by means of canonical variate analysis. 
specimens of the four putative species to collect even numbers of the field specimens.

Correlation tests among morphology, genetics, and geographic origin. The field population assigned as $S$. grossulariifolia grouped morphologically and genetically with the populations assigned as $S$. coccinea in cluster analysis (Fig. 4A-B). The field population assigned as $S$. munroana was morphologically closely related to the composite group of $S$. coccinea and $S$. grossulariifolia but grouped genetically with the populations assigned as S. parvifolia. This result was consistent with those from the morphological and genetic studies distinguishing the composite groups $S$. coccinea and $S$. grossulariifolia, and $S$. munroana and S. parvifolia, further supporting the possibility of hybridization between S. grossulariifolia and S. munroana.

There was a correlation between morphological and genetic distances when all putative species pooled together in Mantel's correlation tests (Table 4) but was not significant within each composite group. The correlation between geographical and genetic distances was significant within both composite groups but not significant when all species pooled together. Only within the $S$. munroana and $S$. parvifolia composite group was the correlation between geographical and morphological distances significant.

The Mantel's correlation test between AFLP genetic and geographical distances was used by Larson et al. (2010) for species delimitation tests of the endemic Lepidium papilliferum (L.F. Hend.) A. Nelson \& J.F. Macbr. Similar to their approach, the correlation between AFLP genetic distance and geographical distance was not significant when all putative species pooled together (Table 4). This result is interpreted, as described by Good and Wake (1992) regarding species delimitation, as being different species. However, the correlation was significant when tested within each composite group, suggesting putative species within each composite group as being non-specific species and isolated by distance (Good and Wake, 1992). In addition, the significant correlation between geographical and morphological distances within the $S$. munroana and $S$. parvifolia composite group supports the Atwood and Welsh (2002) morphological isolation-by-distance findings within this group.

Utah is separated by the Rocky Mountains into two major ecoregions, including the Northwest ecoregion (Great Basin) and the Southeast ecoregion (Colorado Plateau). The Colorado Plateau differs from the Great Basin in having greater summer rainfall as a result of frontal systems moving northward from the Gulf of California, sandier soils, and streams, which drain into river systems rather than closed basins and salt playas. These differences result in relatively more favorable conditions during the growing season on the Colorado Plateau and somewhat greater diversification of plant habit, phenology, and physiology (Comstock and Ehleringer, 1992). According to the map of distribution (Fig. 1), the populations assigned as S. parvifolia (p1,
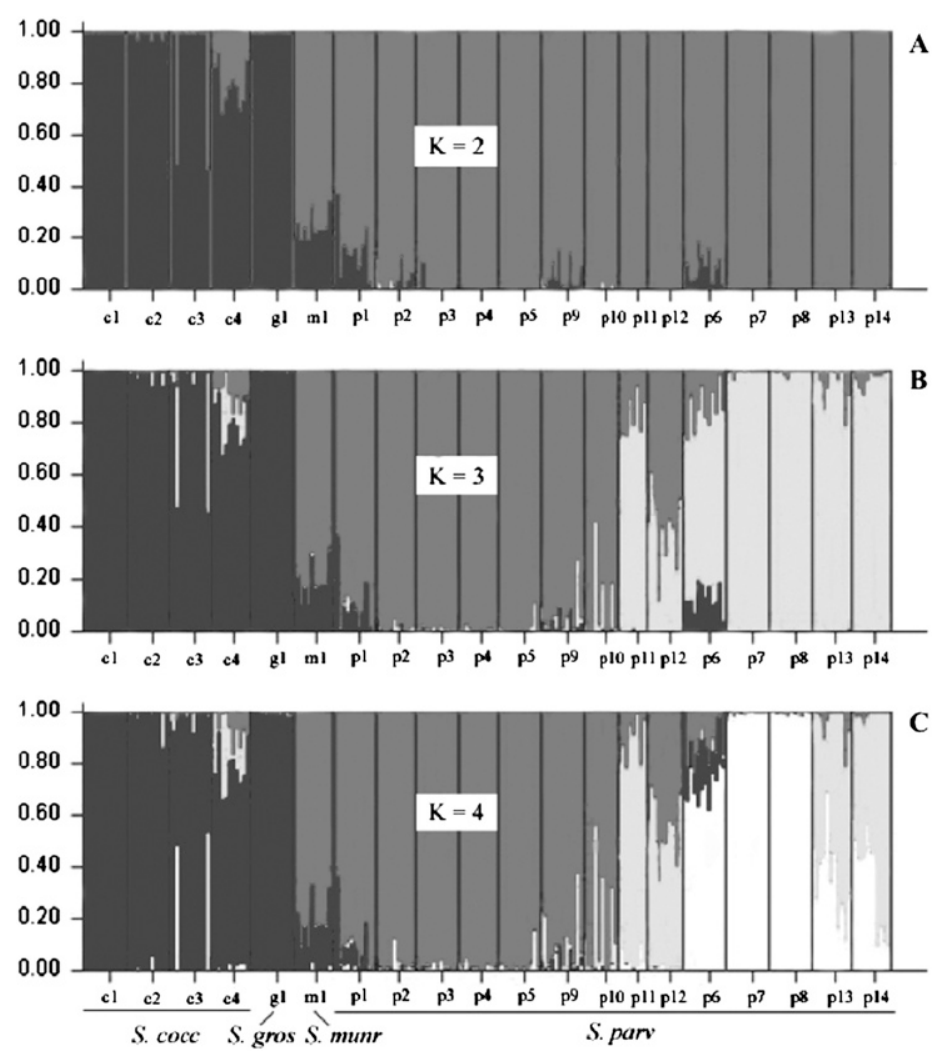

Fig. 3. Inferred population structure of Sphaeralcea amplified fragment length polymorphism genotypes from the field specimens when (A) testing a two population model $(\mathrm{K}=2)$; (B) testing a threepopulation model $(K=3)$; and $(\mathbf{C})$ testing a four-population model $(K=4)$; a thin vertical line represents each individual; black lines separate individuals of different populations; $S$. cocc $=S$. coccinea $;.$ gros $=S$. grossulariifolia; $S$. munr $=S$. munroana; $S$. parv $=S$. parvifolia.
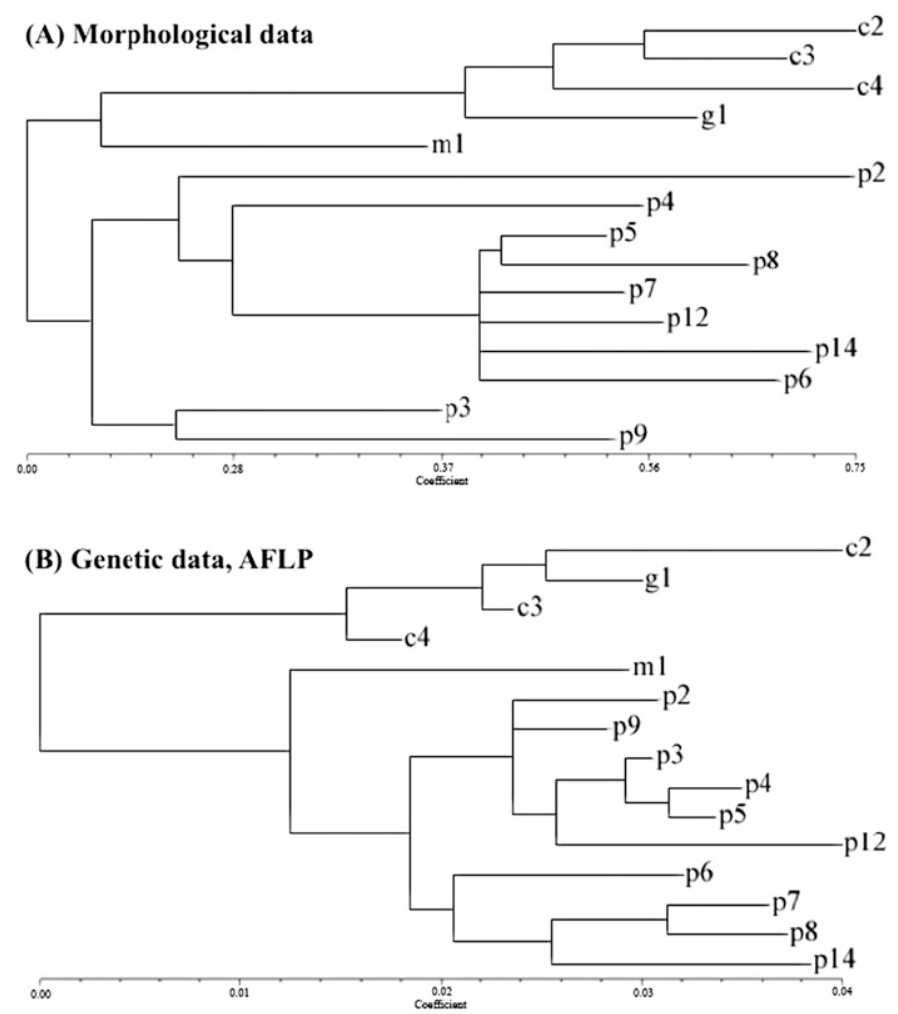

Fig. 4. Neighbor-joining clustering trees constructed from morphological and amplified fragment length polymorphism genetic data of field collection of Sphaeralcea species, where abbreviations c $=S$. coccinea; $\mathrm{g}=S$. grossulariifolia $; \mathrm{m}=S$. munroana; $\mathrm{p}=S$. parvifolia. (A) Tree constructed from Euclidean distances of morphology; (B) the tree constructed from NEI-72 genetic distances. 
Table 4. Mantel's correlation tests performed with 999 permutations of morphological (Euclidean distances of morphology), genetic (NEI-72 genetic distances), and geographic distances of the field specimens assigned on the basis of the classification model as $S$. coccinea, $S$. grossulariifolia, S. munroana, and S. parvifolia.

\begin{tabular}{lccc}
\hline & All $(\mathrm{n}=15)$ & $\begin{array}{c}\text { S. coccinea } \\
(\mathrm{n}=3) \text { and }\end{array}$ & $\begin{array}{c}\text { S. parvifolia } \\
(\mathrm{n}=10) \text { and }\end{array}$ \\
$\begin{array}{l}\text { Geographical genetic } \\
\text { distances }\end{array}$ & $\mathrm{NS}$ & $P=0.038 ; r=0.978$ & $P=0.024 ; r=0.384$ \\
$\begin{array}{l}\text { Geographical-morphological } \\
\text { distances }\end{array}$ & $\mathrm{NS}$ & $\mathrm{NS}$ & $P=0.011 ; r=0.437$ \\
$\begin{array}{l}\text { Morphological-genetic } \\
\text { distances }\end{array}$ & $P=0.001 ; r=0.665$ & $\mathrm{NS}$ & $\mathrm{NS}$ \\
\hline
\end{tabular}

NS = nonsignificant.

p2, p3, p4, p5, p9, p10) and the population assigned as $S$. munroana $(\mathrm{m} 1)$ fell into the Great Basin ecoregion and shared genetic similarity and grouped together in the structure analysis (Fig. 3C). The other populations of the field specimens assigned as $S$. parvifolia fell into the Colorado Plateau ecoregion according to their geographical distribution.

On the basis of genetic similarity, the populations assigned as $S$. parvifolia within the Colorado Plateau ecoregion group suggested by the structure analysis can be separated into two subgroups (Fig. 3C). The first subgroup included $S$. parvifolia, population $\mathrm{p} 6, \mathrm{p} 7$, and p8. All populations in this subgroup were collected in Emery County, in the central east section of Utah (Fig. 1). The other subgroup included $S$. parvifolia, population $\mathrm{p} 11, \mathrm{p} 12$, $\mathrm{p} 13$, and $\mathrm{p} 14$. The populations $\mathrm{p} 11$ and p12 were collected from southwestern Utah, and the populations p13 and p14 were collected from southeastern Utah. The populations p13 and p14 also shared genetic similarity with the other subgroup (p6, p7, p8) (Fig. 3C).

Morphological adaptation to different environmental settings may account for leaf morphological variation among populations of the S. parvifolia and S. munroana composite group. Leaf dissection could be a tradeoff with pubescence, because both reduce heating: dissection through greater convection, hairs through solar radiation reflection, with the hairs having the additional benefit of reducing boundary layer conductance. Anecdotally, leaves of $S$. parvifolia in the Colorado plateau were relatively densely pubescent but less lobed than S. parvifolia in the Great Basin. Within the Colorado plateau group, leaf pubescence of the populations from the south (p11, p12, p13, p14) was relatively dense compared with that of the populations from the central east section of Utah (p6, p7, p8). The dense pubescence may be an adaptation to the relatively hotter temperatures in the south, thus a lower transpiration rate and less rapid soil water depletion.

The results from morphological, genetic, and correlation studies support two pure types among the four putative species. Sphaeralcea grossulariifolia grouped morphologically and genetically with $S$. coccinea, whereas $S$. munroana grouped morphologically and genetically with $S$. parvifolia. The morphological variation among populations of $S$. munroana and $S$. parvifolia correlated with geographical distances. Therefore, source identification can be useful in developing plant material for lowwater landscaping in the Intermountain West from these Sphaeralcea species. When combined with selection and vegetative propagation of superior clones, source identification based on ecological settings within a composite group can provide more confidence in native plant production being brought to market.

\section{Literature Cited}

Atwood, N.D. and S.L. Welsh. 2002. Overview of Sphaeralcea (Malvaceae) in southern Utah and northern Arizona, USA, and description of a new species. Novon 12:159-166.

Cane, J.H. and L. Kervin. 2009. Gardening for native bees in Utah and beyond. Utah Pests Fact Sheet. 10.

Comstock, J.P. and J.R. Ehleringer. 1992. Plant adaptation in the Great Basin and Colorado Plateau. Great Basin Nat. 52:195-215.

Deloya, M.C. 1993. Urban forestry in Mexico City. Unasylva 173:28-32.

Falush, D., M. Stephens, and K. Pritchard. 2007. Inference of population structure using multilocus genotype data: Dominant markers and null alleles. Mol. Ecol. 7:574-578.

Foster, H.S. and B.R. Beattie. 1979. Urban residential demand for water in the United States. Land Econ. 55:43-58.

Good, D.A. and D.B. Wake. 1992. Geographic variation and speciation in the torrent salamanders of the genus Rhyacotriton (Caudata: Rhyacotritonidae). Univ. Calif. Publ. Zool. 126:1-91.

Holmgren, N.H., P.K. Holmgren, and A. Cronquist. 2005. Intermountain flora: Vascular plants of the Intermountain West, USA. Vol. 2, part B, subclass Dilleniidae. The New York Botanical Garden Press, New York, NY.

Intermountain Native Plant Growers Association. 2012. Utah's choice program. Intermountain Native Plant Growers Association. 30 Mar. 2012. <http://www.utahschoice.org/ utahscho/ choice/parennials>.

Kjelgren, R., L. Wang, and D. Joyce. 2009. Water deficit stress responses of three native Australian ornamental herbaceous wildflower species for water-wise landscapes. HortScience 44:1358-1365.

Kratsch, H.A. 2011. Water-efficient landscaping in the Intermountain West: A professional and do-ityourself guide. Utah State Univ. Press, Logan, UT.
La Duke, J.C. and D.K. Northington. 1978. The systematics of Sphaeralcea coccinea (Nutt.) Rydb. (Malvaceae). Southwest. Nat. 23:651660.

Larson, S.R., C.M. Culumber, R.N. Schweigert, and N.J. Chatterton. 2010. Species delimitation tests of endemic Lepidium papilliferum and identification of other possible evolutionarily significant units in the Lepidium montanum complex (Brassicaceae) of western North America. Conserv. Genet. 11:57-76.

Maas, J., R.A. Verheij, P.P. Groenewegen, S. de Vries, and P. Spreeuwenberg. 2006. Green space, urbanity, and health: How strong is the relation? J. Epidemiol. Community Health 60:587-592.

Mantel, N. and R.S. Valand. 1970. A technique of nonparametric multivariate analysis. Biometrics 26:547-558.

McKinney, M.L. 2002. Urbanization, biodiversity, and conservation. Bioscience 52:883-890.

Mee, W., J. Barnes, R. Kjelgren, R. Sutton, T. Cerny, and C. Johnson. 2003. Water Wise: Native Plants for Intermountain Landscapes. Utah State Univ. Press, Logan, UT.

Meyer, S.E., R.K. Kjelgren, D.G. Morrison, W.A. Varga, and B. Schultz. 2009. Landscaping on the new frontier: Waterwise design for the Intermountain West. Utah State Univ. Press, Logan, UT.

Peppin, D.L., P.Z. Fule, J.C. Lynn, A.L. MottekLucas, and C.H. Sieg. 2010. Market perceptions and opportunities for native plant production on the southern Colorado plateau. Restor. Ecol. 18:113-124.

Pritchard, J.K., M. Stephens, and P. Donnelly. 2000. Interference of population structure using multilocus genotype data. Genetics 155 : 945-959.

Ring, G. 2005. A checklist of the vascular flora of Canyon de Chelly National Monument, Apache County, Arizona. J. Torrey Bot. Soc. 132:510 532.

Ring, G.R. and A.C. Cully. 2007. A checklist of the vascular flora of Yucca House National Monument and surrounding lands, Montezuma County, Colorado. J. Torrey Bot. Soc. 134:289-300.

Ring, G.R., A.C. Cully, and D.A. McCallum. 2009. A checklist of the vascular flora of El Morro National Monument, Cibola County, New Mexico. J. Torrey Bot. Soc. 136:403-421.

Shultz, L.M., R.D. Ramsey, W. Lindquist, and C. Garrard. 2012. Digital atlas of the vascular plants of Utah. Utah State University. 30 Mar 2012. <http://www.earth.gis.usu.edu/plants $>$.

Tate, J.A. 2002. Systematics and evolution of Tarasa Philippi (Malvaceae): An enigmatic Andean polyploidy genus. $\mathrm{PhD}$ diss., Univ. Texas, Austin, TX

United Nations. 2012. World urbanization prospects: The 2007 population database. United Nations Population Division. 30 Mar. 2012. <http:// www.esa.un.org/unup/index.asp?panel=1>.

United States Department of Agriculture. 2012. Plants profile. Natural Resources Conservation Service. 30 Mar. 2012. <http://www.plants.usda. gov/java/profile?symbol=SPCO $>$.

Vorosmarty, C.J., P. Green, J. Salisbury, and R.B. Lammers. 2000. Global water resources: Vulnerability from climate change and population growth. Science 289:284-288.

Vos, P., R. Hogers, M. Bleeker, M. Reijans, T. Van de Lee, M. Hornes, A. Frijters, L. Pot, J. Peleman, M. Kuiper, and M. Zabeau. 1995. AFLP: A new technique for DNA fingerprinting. Nucleic Acids Res. 23:4407-4414. 